\title{
ARTICLES
}

Submitted 09.14.2016. Approved 10.16.2017

Evaluated through a double-blind review process. Scientific Editor: Mateus Canniatti Ponchio

Original version

DOI: http://dx.doi.org/10.1590/So034-759020180206

\section{DIMENSIONALITY AND EFFECTS OF INFORMATION MOTIVATION ON USERS' ONLINE SOCIAL NETWORK ADVERTISING ACCEPTANCE}

\author{
Dimensão e efeitos da motivação da informação sobre a aceitação dos \\ usuários da publicidade nas redes sociais \\ Dimensionalidad y efectos de la motivación de la información en la aceptación \\ de la publicidad de las redes sociales online de los usuarios
}

\begin{abstract}
Social media has produced substantial changes in the communication landscape. Online social network sites (SNS) grew as a common platform for online social interaction. SNS firms generate revenue from the advertising appearing on SNS. Their survival depends on users' approval of such social network advertising (SNA). Marketing literature indicates that users accept advertising if it is consistent with their motivations for using social media. Information seeking is the most recognized SNS motivation. Yet, research on evaluating the influence of SNS information motivation on users' approval of SNA is scarce. Based on SNS uses and gratifications theory, this study proposes a multidimensional model that shows the influence of SNS information motivation on users' approval of SNA.
\end{abstract}

KEYWORDS | Social network sites, information motivation, social network advertising, attitude, behavior

\section{RESUMO}

As redes sociais produziram modificações significativas no panorama da comunicação. Os sites de rede sociais (SRS) cresceram como uma plataforma comum para a interação social. As empresas de SRS geram receitas de publicidade que aparecem nos SRS. A sobrevivência dessas empresas depende da aprovação dos usuários de publicidade nas redes sociais (PRS). A literatura sobre o Marketing indica que os usuários aceitam a publicidade se esta for compatível com as suas motivações para o uso de meios de comunicação sociais. A busca de informações, assim como as pesquisas que avaliam a influência da motivação da informação do SRS sobre a aprovação dos usuários de PRS, é a motivação mais reconhecida dos SRS. Baseado na teoria de usos e gratificações do SRS, este estudo propõe um modelo multidimensional que mostra a influência da motivação da informação do SRS na aprovação de usuários de PRS.

PALAVRAS-CHAVE / Sites de redes sociais, motivação da informação, publicidade nas redes sociais, atitude, comportamento.

\section{RESUMEN}

Las redes sociales han producido cambios sustanciales en el panorama de la comunicación. Los sitios de redes sociales online (SNS) crecieron como plataforma común para la interacción social online. Las empresas de SNS generan ingresos de la aparición de publicidad en SNS. Su supervivencia depende de la aprobación de los usuarios de dicha publicidad en redes sociales (SNA). La literatura de marketing indica que los usuarios aceptan publicidad si es consistente con sus motivaciones para usar las redes sociales. La búsqueda de información es la motivación de SNS más reconocida. También lo es la investigación sobre evaluar la influencia de la motivación de información de SNS en la aprobación de los usuarios de SNA. Con base en la teoría de usos y gratificaciones de SNS, este estudio propone un modelo multidimensional que muestra la influencia de motivación de información de SNS en la aprobación de los usuarios de SNA.

PALABRAS CLAVE / Sitios de redes sociales, motivación de información, publicidad em redes sociales, actitud, comportamiento. 


\section{INTRODUCTION}

The evolution of social media has modernized the ways of social and commercial communication (Mir \& Rehman, 2013). Social network sites (SNS) in particular have shown rapid user adoption globally (Taylor, Lewin, \& Strutton, 2011) and have become a common place for social interaction (Mir, 2014). SNSs are Web 2.0 based applications that enable online user interactivity (Boyd \& Ellison, 2007). Advertising appearing on an SNS is the principal revenue source for SNS firms, such as Facebook (Trusov, Bodapati, \& Bucklin, 2010). The survival of such firms depends on the users' acceptance of social network advertising (SNA) (Taylor et al., 2011). Mir (2014) suggests that users accept SNA that relates to their respective SNS motivations. Several studies, such as Chen (2012) found information motivation as the most common stimulus that drives people to SNSs. Users join and use SNSs to gather information that is useful for simplifying recognized purchase decisions, improving knowledge, getting inspiration, and verifying existing information (Chu \& Kim, 2011; Kuss \& Griffiths 2011; Muntinga, Moorman, \& Smit, 2011; Park, Kee, \& Valenzuela, 2009). Despite the relevance of information motivation in SNSs, few researchers, such as Chi (2011), Mir (2014), and Taylor et al. (2011) assessed its influence on users' approval of the SNA. However, these researchers theorized SNS information motivation as a single dimensional construct. Literature indicates that it is a multidimensional construct. Identifying the dimensions of information motivation is indispensable because they influence attitude and behavior differently (Bloch, Sherrell, \& Ridgway, 1986; Touré-Tillery \& Fishbach, 2014).

In addition, past research (Taylor et al., 2011) measured the impact of SNS information motivation only on user attitudes toward SNA. A favorable user attitude does not guarantee the success of advertising unless it stimulates click-through behavior. Ad click behavior provides the numerical summation of users who see these ads. Yet, it does not reveal how it impacts users' online buying behavior (Briggs \& Hollis, 1997). For the successful execution of SNA, these points need to be addressed and therefore, this study identifies the various dimensions of SNS information motivation. Furthermore, it examines the mediated and direct effects of these dimensions on users' SNS ad clicking behavior. To obtain the complete picture of SNS ad click exposure, the influence of SNS ad clicking behavior on users' online buying behavior is also measured. The relationship of SNS information motivation with user acceptance of SNA is modeled using the uses and gratifications theory (UGT).

\section{INFORMATION MOTIVATION}

Information motivation is defined as the goal-directed activities performed by users to fulfill certain information needs and motives (Rubin, 1984). It is one of the most common SNS motivations (Kim, Shim, \& Ahn, 2011). Past studies (Chew, 1994; Weigts, Widdershoven, Kok, \& Tomlow, 1993; Wilson, 1999) identified information motivation as a multidimensional construct. For instance, Muntinga et al. (2011) discovered surveillance, knowledge, pre-purchase information search, and inspiration as dimensions of information motivation that drive users to consume social media brand content. Gratifications studies (Chu \& Kim, 2011; Kuss \& Griffiths, 2011) identified that users participate in SNS to gather information to support their purchase decisions, improve their knowledge, get inspiration, and verify existing product information. Consistent with a few past studies (Muntinga et al., 2011; Wilson, 1999), this study proposes pre-purchase search, inspiration, ongoing search, and verification as dimensions of SNS information motivation. These dimensions are derived from different information needs of users. For example, pre-purchase search is derived from the need to support purchase decisions ( $\mathrm{Ha}, 2002)$. Ongoing search relates to the need of building knowledge banks (Bloch et al., 1986). Inspiration is based on the need to locate novel consumption ideas (Muntinga et al., 2011). Similarly, verification is derived from the need to ensure that a person possesses the right information (Chew, 1994). According to Petter, Straub, and Rai (2007), multidimensional constructs are formative in nature. Formative constructs present the complete portrayal of the issue being studied. Since the dimensions of a formative construct capture different aspects of a phenomenon, they may have different consequences (Jarvis, MacKenzie, \& Podsakoff, 2003). Consistent with this argument, previous researches, such as those by Bloch et al. (1986) and Touré-Tillery and Fishbach (2014), claim that the dimensions of information motivation influence user attitudes and behavior differently. Details on the dimensions of SNSs information motivation are provided in the following sections.

\section{Pre-purchase search}

According to Mir (2014), pre-purchase search refers to information exploration and management behavior that users exhibit to streamline recognized buying decisions. Past studies, such as those by Park et al. (2009), discovered that users use an SNS to gather valuable facts that helps them in selecting the right products. Particularly, users collect product-related information 
on SNSs (e.g., on Facebook) to minimize the risk of making flawed buying decisions. Users usually seek other users' product views on the web to minimize the perceived purchase risk. SNSs enable users to obtain the informational tip-offs and suggestions that are helpful in addressing the product purchase related issues (Goldsmith \& Horowitz, 2006). Some researchers (e.g., Punj \& Staelin, 1983) declared pre-purchase information search as the principal motivation that drives consumers to use media. The information provided by the media increases brand comprehension and helps consumers in making quality purchase decisions and consumption choices (Ha, 2002).

\section{Inspiration}

Inspiration is a significant motivating factor that drives users to social media. Consuming brand content available on social media inspires users. Social media brand content helps generate new consumption ideas (Muntinga et al., 2011). Particularly, users participate in SNSs to observe consumption patterns of other users, such as what they purchase, how they purchase, and how they use products across consumptions situations. Today, users rely on social media to discover inspiring brand content prior to acquiring a product (Cisco, 2012). For instance, users visit online showrooms for inspiration before buying a car. According to Densten (2002), inspirational motivation is categorized into two types. One is image-based and the other is concept-based. On SNSs, such as Facebook, users frequently upload pictures and video clips of their consumption activities. In addition, they write about their consumption patterns in the form of opinions, comments, and views. The user-generated imagery and conceptbased brand content inspire other SNS users to buy specific products.

\section{Ongoing search}

According to Bloch et al. (1986), ongoing search is a notable motivation that leads users to social media. The motives behind ongoing search are diverse. For instance, users conduct ongoing search to develop their knowledge banks (Bloch et al., 1986) and update their knowledge (Grant, 2005). Users' ongoing search behavior is not related to some precise need or buying decision (Bloch et al., 1986). Ongoing search enhances purchasing efficiencies, leads to impulse buying, and influences opinion leadership. It acquaints users with product functionalities. It is an important predictor of media consumption (Diddi \& LaRose, 2006). Ongoing search has been found to be an important users' SNS motivation. Users participate in SNSs to enrich their product and brand knowledge. SNSs expose them to a copious amount of information (Kuss \& Griffiths, 2011).

\section{Verification}

Users receive enormous product information from multiple sources (e.g., friends, print media, electronic media, and the Internet) daily. Yet, information obtained from different sources may not be equally reliable for them. They may perceive some information to be credible and accurate, while the rest to be erroneous. In such a situation, users face the challenge of verifying the precision of the information (Hilligoss \& Rieh, 2008). According to Rieh and Hilligoss (2008), when users suspect inconsistencies in information obtained from various sources, they attempt to verify it. Gathering information to verify the reliability of the existing product information is an important user need (Weigts et al., 1993). Users use media to find the information useful to verify the accuracy of the existing product information (Wilson, 1999). Many users perceive the information presented on social media, such as on SNSs accurate and credible (Al Jenaibi, 2011). Since users regard the information that their friends recommend on SNSs credible and reliable, they may depend on a particular SNS as a place to verify the credibility and accuracy of the information that they receive from multiple sources socially (Chu \& Kim, 2011).

\section{THEORETICAL FOUNDATIONS AND CONCEPTUAL MODEL}

Motivations are the key stimuli that drive users to join and use SNSs (Chi, 2011). Understanding the users' SNS motivations is therefore critical for the success of SNS firms and SNS advertisers (Taylor et al., 2011). Papacharissi and Rubin (2000) defined motivations as inclinations that drive a person to satisfy his or her needs and wants. Gratifications researches by Kim et al. (2011) and Chen (2012) found information seeking as the most common SNS motivation. Information motivation is derived from the users' need for information acquisition (Katz, Gurevitch, \& Hass, 1973). The present research employs UGT to rationalize the SNS information motivation dimensions, as well as their effects (mediated and direct) on SNS users' banner ad clicking behavior. UGT is also employed to explain the impact of SNS banner ad clicking behavior on users' online buying behavior.

The review by Ruggiero (2000) shows that UGT lacks theoretical and operational grounds. Yet, it is considered to be a valuable theory to grasp users' media usage motivations (Ruggiero, 2000). Rosengren, Wenner, and Palmgreen (1985) state that lack of theoretical explanatory power and operational 
elusiveness in UGT allows researchers to amend this theory according to the research situation. Previous research by Orchard, Fullwood, Galbraith, and Morris (2014) and Al-Menayes (2015) identified UGT as appropriate to measure users' SNS motivations. Similarly, Taylor et al. (2011) and Mir (2014) discovered UGT to be an appropriate theoretical framework to assess the influence of SNS motivations on users' acceptance of SNS advertising.

Severin and Tankard (1997) stated that the focus of UGT is on the user. It explains the reasons that stimulate users to use different media. By applying UGT, several studies, such as those by Korgaonkar and Wolin (1999) and Taylor et al. (2011), identified that users use conventional media (e.g., television) and online media (e.g., social media) for the fulfillment of different information-related needs and motives. Similarly, SNS gratifications literature unveils that people use SNSs to fulfil various information needs. For instance, users participate in an SNS to collect the information that they can use to simplify their buying decisions (Park et al., 2009), improve their knowledge (Kuss \& Griffiths, 2011), get inspiration (Muntinga et al., 2011), and verify the accuracy of existing information (Chu \& Kim, 2011). These findings indicate that SNS information motivation is a multidimensional construct. Based on UGT and gratifications literature, this study proposes that SNS information motivation is a multifaceted construct comprising pre-purchase search, inspiration, ongoing search, and verification motivations (see Figure 1). According to Johnson, Rosen, Chang, Djurdjevic, and Taing (2012), a relevant theory should explain the multidimensionality of a construct. Both theory and relevant literature should specify the underlying dimensions of the construct. Based on the conceptualization mentioned above, the following hypothesis is set forth:

H1: SNS information motivation is a multidimensional construct consisting of "pre-purchase search, inspiration, on-going search, and verification factors.”

Figure 1. SNS information motivation based user acceptance model of SNA

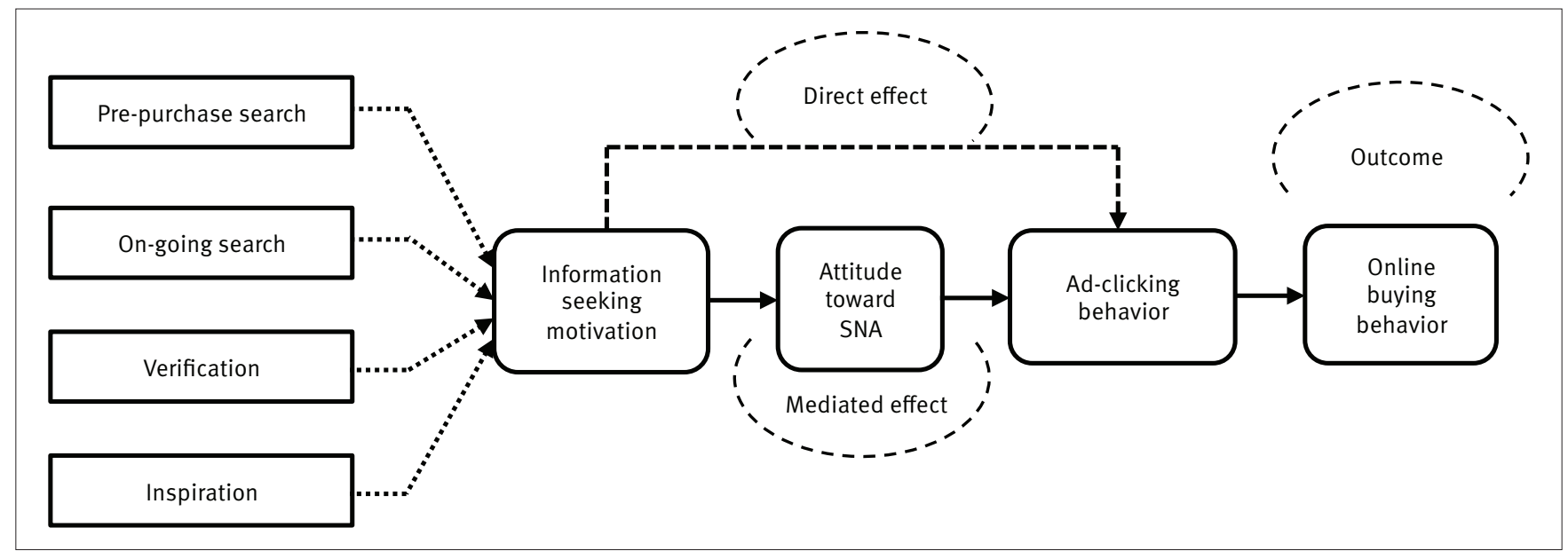

According to Petrovici and Marinov (2007), information seeking is the key motivation that positively impacts the users' attitude towards advertising. SNS information motivation exposes users to the SNS banner ads (Trusov et al., 2010). Chou, Rashad, and Grossman (2008) found that exposure to the ads impacts the users' attitude towards advertising. According to Fishbein and Ajzen (1975), attitude is a person's favorable or unfavorable emotional state and psychological judgment to execute a certain behavior. Taylor et al. (2011) found a positive causal association between SNS information motivation and user attitudes toward SNA. In marketing literature, the mediating role of attitude is well established (MacKenzie, Lutz, \& Belch, 1986). Mir (2014) found that users' attitude towards SNA plays a mediating role between
SNS motivations and users' ad clicking behavior. An ad click indicates an action initiated by users that redirects them from the SNS web page to an advertiser's homepage. On the advertiser's homepage, users receive more information and may buy the product there (Mir, 2012). Consistent with past gratifications research, this study postulates that attitude towards SNA mediates the causal association between SNS information motivation and users' SNS display ad clicking behavior. This causal association is proposed to be positive (see Figure 1). Yet, this attitudinal mediation may be partial because each dimension of information motivation differently affects the user attitudes and behaviors (Bloch et al., 1986; Touré-Tillery \& Fishbach, 2014). Based on the aforementioned theorization, the following hypothesis is set forth: 
H2: Attitudes toward SNA mediate the causal association between SNS information motivation and users' SNS banner ad clicking behavior.

Besides the mediated effect, motivations have been found to directly impact users' ad clicking behavior (Burgess, 2015). Motives to use the Internet expose users to Internet advertising, which in turn stimulate users' Internet ad clicking behavior (Chatterjee, 2008; Yoo, 2008). This study postulates that SNS information motivation influences users' SNS banner ad clicking behavior directly and positively (see Figure 1). However, all dimensions of SNS information motivation may not equally influence the users' SNS banner ad clicking behavior. According to Bloch et al. (1986), each dimension of information motivation has a varying effect on the users' search behavior. Furthermore, Briggs and Hollis (1997) state that ad clicking behavior provides the numerical summation of users who see these ads. Yet, it does not reveal how it impacts the users' online buying behavior. Therefore, this study proposes that users' SNS banner ad clicking behavior positively influences their online buying behavior (see Figure 1). This supposition is supported by Mir (2012) who found that users' social media banner ad clicking behavior positively influences their online buying behavior. The following hypotheses are stated based on the conceptualization mentioned above.

$\mathrm{H}_{3}$ : SNS information motivation has a direct and positive impact on users' SNS banner ad clicking behavior.

$\mathrm{H}_{4}$ : Users' SNS banner ad clicking behavior has a positive influence on their online buying behavior.

\section{METHOD}

\section{Sample}

Data were collected from 450 undergraduate and graduate (274 male and 176 female) students via two offline surveys. Past researchers (e.g., Chu, 2011) collected cross sectional data via surveys to test the causal models on SNA. Students were sampled from two capital and four provincial universities in Pakistan using a simple random sampling (SRS) procedure. The aggregate students of these universities were 47,490. Yamane's (1967) formula provided a sample size of 397 . Nonetheless, a sample size of 450 was used. Lists of students were obtained from each university and each student was given a number. Samples were drawn from each list using a lottery method of sampling. First, the data from 200 students were collected to conduct the pilot study. In the second phase of the research, data of the pilot study were incorporated into the data collected from 250 students to test the theoretical model of SNA acceptance. According to Lancaster, Dodd, and Williamson (2004), in case of the SRS pilot study is part of the main study. It is conducted using data from some percentage of the total sample size. The data of both the pilot and main studies were combined to test the theoretical model. In both phases of this research, the sample size was divided among the chosen universities based on their student ratios in the aggregate population. The targeted students were Facebook, Google+, and MySpace users. The ages of the majority of sampled students were between 20 and 25 years. Students were targeted because they actively use SNSs, spend sufficient time on SNSs daily (Mir, 2012), and are the main targets of SNA campaigns (Chu, 2011). The questionnaire focused on personal wear (i.e., t-shirts and wrist watches) and personal use devices (i.e., laptops and mobile handsets) product categories.

\section{Measurement, content validity, and pretest}

To measure the SNS information motivation, a pool of 28 items was developed from past studies (Ancu \& Cozma, 2009; Cisco, 2012; Chu \& Kim, 2011; Goldsmith \& Horowitz, 2006; Grant, 2005; Korgaonkar \& Wolin, 1999; Muntinga et al., 2011; Rodgers, Wang, Rettie, \& Alpert, 2007; Weigts et al., 1993). The deductive method of scale development (Clark \& Watson, 1995) was employed to choose the items. Comprehensive literature review and theorization of SNS information motivation was performed to guide the item generation as recommended by Hinkin (1995). User responses were recorded on a 5-point Likert scale, varying from 1 (strongly disagree) to 5 (strongly agree). To evaluate the content validity of SNS information motivation measures, relevant literature review and two subject experts were used (Straub, 1989). Before the main surveys, 25 students assessed the comprehensibility of the questions.

\section{Pilot study}

To reduce the pool of items measuring SNS information motivation and to detect its dimensions, principal component analysis (PCA) was performed on the data collected from a sample of 200 students. PCA was employed with orthogonal rotation using the varimax method. In case of data reduction, PCA is performed. Orthogonal rotation with the varimax method is used because it yields simple and true underlying factors of a construct (Floyd \& Widaman, 1995) with high and low loadings (Fabrigar, Wegener, MacCallum, \& Strahan, 1999). The criteria of item communalities $>0,40$ and factor loadings >0,60 were used to retain the items. 
To retain the components (factors) of SNS information motivation, the criterion of eigenvalue >1.00 was applied. PCA yielded four factors of SNS information motivation: “Pre-purchase Search” (F1) (a=0.81), “Inspiration” (F2) ( $a=0.83)$, “On-going Search” (F3) $(a=0.72)$, and "Verification" (F4) ( $a=0.75)$ after four iterations. Kaiser-Meyer-Olkin (KMO) measure of sample adequacy = 0.81 and Bartlett's test of sphericity $=000$ ensured the successful application of PCA on the data. The PCA confirmed the formative nature of the SNS information motivation as it produced its four factors (dimensions) capturing different themes (Jarvis et al., 2003). Table 1 shows the detailed PCA results.

Table 1. PCA rotated factor solution for SNS information motivation

\begin{tabular}{|c|c|c|c|c|}
\hline & $\mathrm{F}_{1}$ & $F_{2}$ & $\mathrm{~F}_{3}$ & $\mathrm{~F}_{4}$ \\
\hline Measures & $\begin{array}{l}\text { Pre-purchase } \\
\text { search }\end{array}$ & Inspiration & $\begin{array}{l}\text { On-going } \\
\text { search }\end{array}$ & Verification \\
\hline \multicolumn{5}{|l|}{ I use SNS: } \\
\hline $\begin{array}{l}\text { To find the recommendations and advice to support my purchase } \\
\text { decisions }\end{array}$ & 0.714 & - & - & - \\
\hline To get in-depth information about products & 0.757 & - & - & - \\
\hline To get the information to make informed buying decisions & 0.781 & - & - & - \\
\hline To learn how to solve problems involved in a purchase decision & 0.713 & - & - & - \\
\hline $\begin{array}{l}\text { To find information to reduce the risk of making a bad product } \\
\text { choice }\end{array}$ & 0.679 & - & - & - \\
\hline To find what people use & - & 0.859 & - & - \\
\hline To find how people buy \& use products & - & 0.819 & - & - \\
\hline To update my product information & - & - & 0.720 & - \\
\hline To enhance my knowledge about different products & - & - & 0.717 & - \\
\hline $\begin{array}{l}\text { Because they give quick } \& \text { easy access to large volumes of } \\
\text { information }\end{array}$ & - & - & 0.771 & - \\
\hline To explore new products & - & - & 0.609 & - \\
\hline When I hear about a new thing I check it out on SNSs & - & - & - & 0.824 \\
\hline Percentage of total variance explained & \multicolumn{4}{|c|}{$63.141 \%$} \\
\hline
\end{tabular}

To examine the goodness of fit and validity of the dimensional structures of the SNS information motivation measurement model, "confirmatory factor analysis" (CFA) was conducted on the data as suggested by Floyd and Widaman (1995). The model with $a x^{2}=123.132, d f=84$, and $P=0.004(p<0.05)$ failed to yield the goodness of fit. Yet, the model showed a good fit to data on the alternate model testing technique (i.e., $x^{2} / \mathrm{df}$ ratio, with a value $1.466<3$ ) (Kline, 1998). The measurement model also presented a good fit to the data on assessment indices (i.e., $\mathrm{GFI}=0.93$, IFI $=0.96, \mathrm{CFI}=0.96, \mathrm{NFI}=0.90, \mathrm{TLI}=0.95$, and RMSEA = 0.04; GFI, IFI, CFI, NFI, and TLI>0.90) (Bentler \& Bonnet, 1980; McDonald \& Ho, 2002). RMSEA 0.08 (MacCallum, Browne, \& Sugawara, 1996) indicated goodness fit of the measurement model. Table 2 shows the detailed CFA results. 
Table 2. SNS information motivation CFA estimates

\begin{tabular}{|c|c|c|c|c|c|c|c|c|}
\hline & Measures & 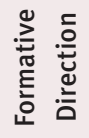 & Factors & Estimate & $\begin{array}{l}\text { Standardized } \\
\text { estimate }\end{array}$ & SE & CR & $\mathbf{P}$ \\
\hline & I use SNS: & & & & & & & \\
\hline 1 & $\begin{array}{c}\text { To find the recommendations and } \\
\text { advice to support my purchase } \\
\text { decisions }\end{array}$ & $\rightarrow$ & $F_{1}$ & 1.000 & 0.619 & - & - & - \\
\hline 2 & $\begin{array}{l}\text { To get in-depth information about } \\
\text { products }\end{array}$ & $\rightarrow$ & $\mathrm{F}_{1}$ & 1.159 & 0.734 & 0.149 & 7.807 & $* \star *$ \\
\hline 3 & $\begin{array}{l}\text { To get the information to make } \\
\text { informed buying decisions }\end{array}$ & $\rightarrow$ & $\mathrm{F}_{1}$ & 1.081 & 0.679 & 0.145 & 7.471 & $\star \star \star *$ \\
\hline 5 & $\begin{array}{l}\text { To find information to reduce the risk } \\
\text { of making a bad product choice }\end{array}$ & $\rightarrow$ & $F_{1}$ & 1.036 & 0.660 & 0.148 & 6.995 & $\star \star \star *$ \\
\hline 6 & To find what people buy & $\rightarrow$ & F2 & 1.000 & 0.774 & - & - & - \\
\hline 7 & To find what people use & $\rightarrow$ & $F_{2}$ & 1.026 & 0.798 & 0.099 & 10.349 & $\star \star \star *$ \\
\hline 8 & $\begin{array}{l}\text { To find how people buy } \& \text { use } \\
\text { products }\end{array}$ & $\rightarrow$ & $\mathrm{F} 2$ & 1.097 & 0.792 & 0.109 & 10.047 & $\star \star \star *$ \\
\hline 11 & $\begin{array}{l}\text { Because they give quick \& easy access } \\
\text { to large volumes of information }\end{array}$ & $\rightarrow$ & $F_{3}$ & 1.116 & 0.687 & 0.167 & 6.685 & $\star \star \star *$ \\
\hline 12 & To explore new products & $\rightarrow$ & $F_{3}$ & 1.002 & 0.606 & 0.167 & 5.987 & 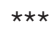 \\
\hline 13 & $\begin{array}{l}\text { When I hear about a new thing I check } \\
\text { it out on SNSs }\end{array}$ & $\rightarrow$ & $\mathrm{F}_{4}$ & 1.000 & 0.758 & - & - & - \\
\hline 14 & $\begin{array}{l}\text { When I hear about a product I check it } \\
\text { out on SNSs }\end{array}$ & $\rightarrow$ & $F_{4}$ & 1.008 & 0.767 & 0.114 & 8.832 & 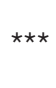 \\
\hline 15 & $\begin{array}{l}\text { To check the authenticity of } \\
\text { information which I receive from my } \\
\text { friends \& relatives offline }\end{array}$ & $\rightarrow$ & $F_{4}$ & 0.737 & 0.622 & 0.102 & 7.249 & $\star \star \star \star$ \\
\hline
\end{tabular}

Note: ${ }^{* * *} \mathrm{p}<0.001$ 


\section{Convergent and discriminant validity}

Convergent validity exhibits how closely associated the measurement items representing a construct are (Gefen \& Straub, 2005). Convergent validity of measures representing factors of SNS information motivation was assessed by evaluating their loadings and t-indices. Statistically significant item loading and $t<-1.96$ and $>+1.96$ (Byrne, 2001) demonstrate convergent validity (Anderson \& Gerbing, 1988; Dunn, Seaker, \& Waller, 1994). The t-index is represented by the critical ratio (CR) in the Amos Software output file. The item loading of measures representing factors of SNS information motivation varied between 60 and 79 and their accompanying t-indices varied between 5.8 and 10.3 at the significance level of .001 that ensured convergent validity (see Table 2).

Discriminant validity of SNS information motivation was assessed by evaluating the inter-factor-correlations ( $r$ ) among the measures of its factors (Shore, Shore, \& Thornton, 1992). The r varied between 0.221 and 0.425 that ensured discriminant validity (see Table 3). Low r (i.e., < 0.70) (Yang, Watkins, \& Marsick, 2004) among the construct measures indicates discriminant validity (Heeler \& Ray, 1972). Furthermore, the square root of the average variance extracted (AVE) was greater than the interfactor correlations of SNS information motivation (See Table 3) that confirmed discriminant validity (Fornell \& Larcker, 1981; Gefen \& Straub, 2005).

\section{Table 3. Discriminant validity matrix of SNS information motivation}

\begin{tabular}{|c|c|c|c|c|c|c|c|c|}
\hline \multirow{2}{*}{$\begin{array}{l}\text { SNS information motivation } \\
\text { Dimensions }\end{array}$} & \multicolumn{4}{|c|}{$\begin{array}{l}\text { Square root of AVE and inter-factor correlation } \\
\text { matrix (from Amos output) }\end{array}$} & \multicolumn{4}{|c|}{$\begin{array}{l}\text { Inter-factor correlation matrix less than } 0.70 \\
\text { (from SPSS output) }\end{array}$} \\
\hline & 1 & 2 & 3 & 4 & 1 & 2 & 3 & 4 \\
\hline Pre-purchase Search & 0.674 & & & & 0.70 & & & \\
\hline On-going Search & 0.388 & 0.265 & 0.625 & & $0.292^{\star \star}$ & $0.221^{\star \star}$ & 0.70 & \\
\hline Verification & 0.368 & 0.339 & 0.534 & 0.719 & $0.277^{\star \star}$ & $0.285^{\star \star}$ & $0.425^{\star \star}$ & 0.70 \\
\hline
\end{tabular}

Note: $\mathrm{N}=200,{ }^{* *} \mathrm{P}<0.01$

\section{Endogenous variables}

Six items were adapted from previous research (Mir, 2012; Taylor et al., 2011) to measure users' attitude toward SNA. Three items from Mir (2012) were adapted to measure users' behavior to click on SNS banner ads. One measure from Mir (2012) was adapted to assess users' online buying behavior. User responses were recorded on a 5-point Likert scale. Internal consistency of endogenous variables that demonstrate to what extent all items in a measurement scale measure the targeted construct (Tavakol \& Dennick, 2011), was assessed via corrected item-total correlation (CITC) and reliability tests. According to Dunn et al. (1994), CITC is conducted to refine the measurement scale prior to assessing its reliability. The criterion of CITC value > 0.50 (Zaichowsky, 1985) was used to retain the items in the scale. The CITC of all items measuring endogenous variables was $>0.05$ (see Table 4). Therefore, they met the precondition of the reliability assessment test. Through Cronbach's alpha coefficient (a), reliability of the endogenous variables was assessed. Attitude towards SNA $(a=0.810)$ and ad clicking behavior $(a=0.833)$ exceeded the acceptable reliability coefficient (i.e., 0.70 ) that ensured internal consistency (Nunnaly, 1978). The online buying behavior scale was not statistically refined as it contained only one item.

\section{MODEL TESTING}

The user acceptance model of SNA based on SNS information motivation was tested on the sample size of 450 . The structural model failed to yield a goodness of fit with $x^{2}=12.175, d f=5$, and $P=0.032(P<0.05)$. Yet, it showed a good fit to the data on the alternate model testing technique $\mathrm{x}^{2} / \mathrm{df}$ ratio with a value $2.435<3 . \mathrm{GFI}=0.992, \mathrm{NFI}=0.975, \mathrm{IFI}=0.985, \mathrm{TLI}=0.935, \mathrm{CFI}=$ 0.985 , and RMSEA $=0.057$ also showed goodness of fit between the model and the data. Figure 2 presents the structural model of SNA acceptance. 
Table 4. Correlated item-total correlation (CITC)

\begin{tabular}{|c|c|c|}
\hline Variable & Measures & CITC \\
\hline \multirow{5}{*}{$\begin{array}{l}\text { Attitude toward } \\
\text { SNA }\end{array}$} & 1. Overall, I consider SNA a good thing & 0.51 \\
\hline & 2. Overall, I like SNA & 0.57 \\
\hline & 3. I consider SNA very essential & 0.64 \\
\hline & 5. My general opinion about SNA is favorable & 0.55 \\
\hline & 6. I like banner ads of products shown on social network sites & 0.52 \\
\hline $\begin{array}{l}\text { Ad-clicking } \\
\text { behavior }\end{array}$ & 3. I often click on ads shown on my SNS profile & 0.67 \\
\hline $\begin{array}{c}\text { Online buying } \\
\text { behavior }\end{array}$ & \multicolumn{2}{|l|}{ 1. I often buy products mentioned in SNS banner ads from website of the company } \\
\hline
\end{tabular}

Figure 2. Structural model of SNA acceptance

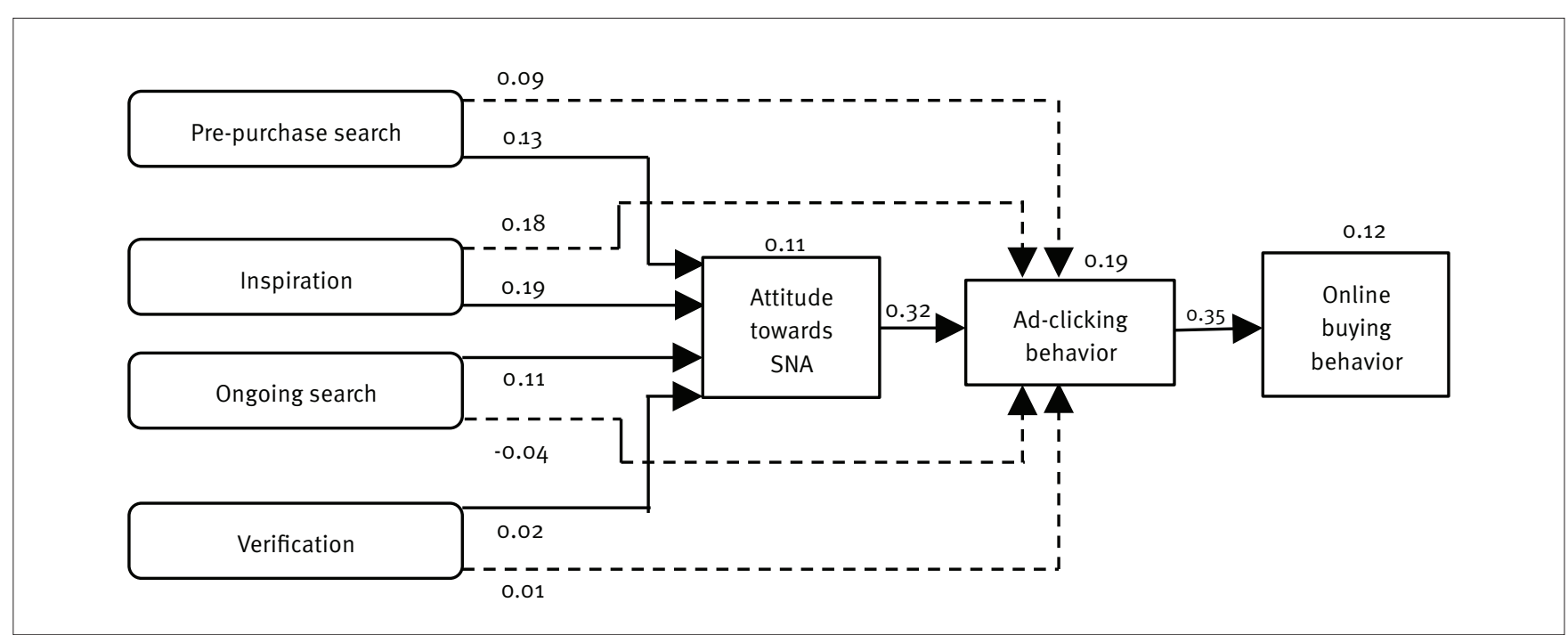

\section{Structural model and hypotheses testing}

The present research discovered "pre-purchase search, inspiration, ongoing search, and verification" as the dimensions of SNS information motivation (see Figure 2) that supported hypothesis $H_{1}$. To evaluate the hypotheses, the path values (i.e., $\beta$, P, and $t$ statistics) between the dimensions of SNS information motivation (exogenous variables) and attitudes toward SNA, ad clicking behavior, and online buying behavior (endogenous variables) were examined. The $P$ and $t$ statistics show the significance of the relationships between variables (Byrne, 2001). The path statistics among "pre-purchase search, inspiration, and ongoing search" and users' attitude toward SNA were $\beta=0.13, P<0.05, t$ $=2.489 ; \beta=0.19, P<0.001, t=3.724 ;$ and $\beta=0.11, P<0.05, t=$ 
2.255, respectively. These values showed significant and positive causal associations between the aforementioned exogenous and endogenous variables. Conversely, the statistics, $\beta=0.02, P$ > 0.05 , and $\mathrm{t}=0.391$, indicated an insignificant causal association between verification and users' attitude toward SNA. The statistics, $\beta=0.32, P<0.001$, and $t=7.073$ between attitudes toward SNA and users' behavior to click on SNS banner ads, indicated a significantly positive causal relationship. Therefore, the overall results partly supported hypothesis $\mathrm{H}_{2}$.

The path statistics, $\beta=0.09, P>0.05, t=1.794 ; \beta=-0.04$, $\mathrm{P}>0.05, \mathrm{t}=-0.775$; and $\beta=0.01, \mathrm{P}>0.05, \mathrm{t}=0.262$, between “pre-purchase search, on-going search, verification, and users' behavior to click on SNS banner ads indicated a non-significant causal association. On the contrary, the statistics, $\beta=0.18, P$ < 0.001 , and $t=3.681$, between inspiration and users' behavior to click on SNS banner ads, respectively, indicated a significantly positive causal relationship. Therefore, the overall results partly supported hypothesis $\mathrm{H}_{3}$. Furthermore, the path statistics, that is, $\beta=0.35, P<0.001$, and $t=7.982$, between users' SNS banner ad clicking behavior and their online buying behavior indicated a significantly positive causal relationship, thereby supporting hypothesis $\mathrm{H}_{4}$.

\section{DISCUSSION}

Since the business model of several SNS firms is based on SNA, identifying the ways of making it effective is indispensable for their survival. Mir (2014) indicates that users will approve SNS advertising if it is compatible with their SNS motives. Past research, such as Chen (2012), found information seeking as the most common SNS motivation. This study identified SNS information motivation as a multifaceted construct containing "pre-purchase search, inspiration, on-going search, and verification" aspects. Some researchers, such as Punj and Staelin (1983) declared pre-purchase information search as the principal motivation that drove consumers to use media. The pre-purchase search leads to product comprehension that is essential for making the right purchase decisions ( $\mathrm{Ha}$, 2002). Several online and SNS gratifications studies (e.g., Goldsmith \& Horowitz, 2006; Park et al., 2009) endorsed the claim by Punj and Staelin. Consistent with the past gratifications research, this study identified "pre-purchase search" as an important dimension of users' SNS information motivation. Users gather information on SNS that is helpful in risk aversion and streamlining purchasing decisions. They do so by reading other SNS users' comments, product views, and reviews (Mir
\& Zaheer, 2012). This study found "inspiration" as the second important dimension of SNS information motivation. Users use SNS to gather inspiring consumption ideas by observing what products and brands other users buy and use. For instance, users get inspiration online by observing what dresses, shoes, etc. other users buy and how they use them (Muntinga et al., 2011). SNS users often share their product experiences in the form of views, photos, and videos. This user-generated content may work as an inspiration for other SNS users and stimulate them to buy some specific brands. This study recognized "ongoing search" as the third significant dimension of SNS information motivation. Users participate in SNSs to explore new products, update product information, and enrich product knowledge. This finding supports the proposition made by Bloch et al. (1986) that along with "pre-purchase search," users are involved in "ongoing search" that is independent of any recognized purchase need or decision. Finally, this study discovered "verification" as the fourth important dimension of SNS information motivation. Users perceive user-generated content on SNSs as accurate, credible, and unbiased (Al Jenaibi, 2011). Therefore, they may rely on an SNS as a place to verify the credibility and accuracy of the information that they receive from multiple sources socially (Chu \& Kim, 2011).

In marketing literature, the mediating role of attitude is well established (Mackenzie et al., 1986). Mir (2014) found that users' attitude toward SNA plays a mediating role between SNS motivations and users' SNS ad clicking behavior. Consistent with past investigations, this research identified that association between SNS information motivation and SNS ad clicking behavior is mediated by the users' attitude toward SNA. However, only pre-purchase search, inspiration, and on-going search positively influence users' attitude towards SNA. Verification insignificantly affected user attitudes toward SNA. This indicates that only former dimensions of SNS information motivation have a mediated effect on users' SNS banner ad clicking behavior. Rodgers (2002) proposed that motivations could directly influence users' online ad clicking behavior. Burgess's (2015) found this supposition true. Consistent with aforementioned researchers, this study discovered that SNS information motivation has a direct and positive impact on users' SNS banner ad clicking behavior. Yet, this effect is true only in case of inspiration. The "pre-purchase search, on-going search, and verification" do not directly influence users' behavior to click on SNS banner ads. These results imply that identifying the dimensions of SNS information motivation is necessary because they influence users' attitude and behavior differently (Bloch et al., 1986; Touré-Tillery \& Fishbach, 2014). 
Marketing literature suggests several reasons for the dimensions of SNS information motivation to behave differently. For instance, pre-purchase search has a positive mediated impact on users' behavior to click on SNS banner ads because they consider advertising information useful for making sensible purchase decisions (O’Donohoe, 1994). Verification has neither a mediated nor direct impact on users' behavior to click on SNS banner ads because advertising is not deemed as a reliable information source for examining the accuracy of other information (Greer, 2003). Inspiration has a positive influence on users' approval of SNA since they consider both commercial and user-generated online brand content as a source of inspiration (Cisco, 2012). Furthermore, ongoing search has a positive mediated influence on users' behavior to click on SNS banner ads because advertising is believed to be useful for improving product knowledge and keeping it current (Jansen, Sobel, \& Cook, 2011).

Consistent with earlier research by Mir (2012), the current study found that SNS banner ad clicking behavior has a positive influence on users' online buying behavior. Briggs and Hollis (1997) stated that clicking on ads does not depict the overall value of online banner advertising. Therefore, knowing the aftereffects of ad clicks is crucial for advertisers. Pavlou and Stewart (2000) stated that clicking on ads generates users' interest in the advertised product that ultimately influences their online buying behavior (Mir, 2014).

\section{CONCLUSION AND LIMITATIONS}

This research identified SNS information motivation as a multifaceted construct containing pre-purchase search, inspiration, ongoing search, and verification dimensions. Each of these dimensions has a differential effect on users' SNA acceptance. Therefore, SNS firms and advertisers should focus on the multi-dimensionality of SNS information motivation to make SNA effective. This study concentrated on traditional display advertising. Researchers should work on unconventional SNA, such as fan pages and brand communities in future studies. Furthermore, the impact of other important user motives, such as identity formation and social impressions on SNA acceptance should also be assessed.

\section{CONTRIBUTION AND IMPLICATIONS}

Unlike earlier investigations, this study identified the dimensions of SNS information motivation. Furthermore, it applied UGT to theorize and operationalize both the mediated and direct impacts of SNS information motivation on SNS users' banner ad clicking behavior. Previous research (e.g., Chi, 2011; Taylor et al. 2011) focused only on SNS users' attitude toward SNS advertising. Moreover, this research examined the influence of users' behavior to click on SNS display ads on their online buying behavior. The results of this investigation imply that SNS firms and advertisers should focus on the dimensions of SNS information motivation when designing SNS banner ads because they influence SNS users' attitude toward SNA and their SNS banner ad clicking behavior differently.

\section{REFERENCES}

Al Jenaibi, B. N. A. (2011). Use of social media in the United Arab Emirates: An initial study. Global Media Journal (Arabian Edition), 1(2), 3-27.

Al-Menayes, J. J. (2015). Motivations for using social media: An exploratory factor analysis. Journal of Psychological Studies, 7(1), 4350. doi:10.5539/ijps.v7n1p43

Ancu, M., \& Cozma, R. (2009). MySpace politics: Uses and gratifications of befriending candidates. Journal of Broadcasting \& Electronic Media, 53(4), 567-583. doi:10.1080/08838150903333064

Anderson, J. C., \& Gerbing, D. W. (1988). Structural equation modeling in practice: A review and recommended two-step approach. Psychological Bulletin, 103(3), 411-423. doi:10.1037/0033- 2909.103.3.411

Bentler, P. M., \& Bonnet, D. C. (1980). Significance tests and goodness of fit in the analysis of covariance structures. Psychological Bulletin, 88(3), 588-606. doi:10.1037/0033- 2909.88.3.588

Bloch, P. H., Sherrell, D. L., \& Ridgway, N. M. (1986). Consumer search: An extended framework. Journal of Consumer Research, 13(1), 119. 126. doi:10.1086/209052

Boyd, D. M., \& Ellison, N.B. (2007). Socialnetworksites: Definition, history, and scholarship. Journal of Computer-Mediated Communication, 13(1), 210-230. doi:10.1111/j.1083-6101.2007.00393.x

Briggs, R., \& N. Hollis, N. (1997). Advertising on the web: Is there response before click-through?. Journal of Advertising Research, 37(2), 33-45.

Burgess, D. (2015). Online banner adverts: More than the final click. Journal of Student Research, 4(2), 94-104.

Byrne, B. M. (2001). Structural equation modeling with Amos: Basic concepts, applications and programming. New Jersey, USA: Lawrence Erlbaum Associates.

Chatterjee, P. (2008). Are unclicked ads wasted? Enduring effects of banner and pop-up ad exposures on brand memory and attitudes. Journal of Electronic Commerce Research, 9(1), 51-61.

Chen, H. (2012). Relationship between motivation and behavior of SNS user. Journal of Software, 7(6), 1265-1272. doi:10.4304/ jsw.7.6.1265-1272 
Chew, E. (1994). The relationship of information needs to issue relevance and media use. Journalism Quarterly, 71(3), 676-688. doi:10.1177/107769909407100318

Chi, H-H. (2011). Interactive digital advertising vs. virtual brand community: Exploratory study of user motivation and social media marketing responses in Taiwan. Journal of Interactive Advertising, 12(1), 44-61. doi:10.1080/15252019.2011.10722190

Chou, S-Y., Rashad, I., \& Grossman, M. (2008). Fast-food restaurant advertising on television and its influence on childhood obesity. Journal of Law and Economics, 51(4), 599-618. doi:10.1086/590132

Chu, S-C. (2011). Viral advertising in social media: Participation in Facebook groups and responses among college-aged users. Journal of Interactive Advertising, 12(1), 30-43. doi:10.1080/15252019.2011.10722189

Chu, S-C., \& Kim, Y. J. (2011). Determinants of consumer engagement in electronic word-of-mouth (eWOM) in social networking sites. International Journal of Advertising, 30(1), 47-75. doi:10.2501/IJA-301-047-075

Cisco. (2012). Digital signage for retail: Attract and keep your customers. Retrieved from www.cisco.com/go/retailsolutions

Clark, L. A., \& Watson, D. (1995). Constructing validity: Basic issues in objective scale development. Psychological Assessment, 7(3), 309319. doi:10.1037/1040-3590.7.3.309

Densten, I. L. (2002). Clarifying inspirational motivation and its relationship to extra effort. Leadership \& Organization Development Journal, 23(1), 40-44. doi:10.1108/01437730210414553

Diddi, A., \& LaRose, R. (2006). Getting hooked on the news: Uses and gratifications and the formation of news habits among college students in an internet environment. Journal of Broadcasting \& Electronic Media, 50(2), 193-210. doi:10.1207/s15506878jobem5002_2

Dunn, S. C., Seaker, R. F., \& Waller, M. A. (1994). Latent variables in business logistics research: Scale development and validation. Journal of Business Logistics, 15(2), 145-172.

Fabrigar, L. R., Wegener, D. T., MacCallum, R. C., \& Strahan, E. J. (1999). Evaluating the use of exploratory factor analysis in psychological research. Psychological Methods, 4(3), 272-299. doi:10.1037/1082$989 X .4 \cdot 3.272$

Fishbein, M., \& Ajzen, I. (1975). Belief, attitude, intention and behaviour: An introduction to theory and research. Reading, UK: Addison-Wesley.

Floyd, F. J., \& Widaman, K.F. (1995). Factor analysis in the development and refinement of clinical assessment instruments. Psychological Assessment, 7(3), 286-299. doi:10.1037/1040-3590.7.3.286

Fornell, C., \& Larcker, D. (1981). Evaluating structural equation models with unobservable variables and measurement error. Journal of Marketing Research, 18(1), 39-50. doi:10.2307/3151312

Gefen, D., \& Straub, D. (2005). A practical guide to factorial validity using PLS-graph: Tutorial and annotated example. Communications of the Association for Information Systems, 16(5), 91-109.
Goldsmith, R. E., \& Horowitz, D. (2006). Measuring motivations for online opinion seeking. Journal of Interactive Advertising, 6(2), 214. doi:10.1080/15252019.2006.10722114

Grant, I. C. (2005). Young peoples' relationships with online marketing practices: An intrusion too far. Journal of Marketing Management, 21(5-6), 607-623. doi:10.1362/0267257054307417

Greer, J. D. (2003). Evaluating the credibility of online information: A test of source and advertising influence. Mass Communication \& Society, 6(1), 11-28. doi:10.1207/S15327825MCSo601_3

Ha, H-Y. (2002). The effects of consumer risk perception on prepurchase information in online auctions: Brand, word-of-mouth, and customized information. Journal of Computer Mediated Communication, 8(1). doi:10.1111/j.1083-6101.2002.tboo16o.x

Heeler, R. M., \& Ray, M. L. (1972). Measure validation in marketing. Journal of Marketing Research, 9(4), 361-370. doi:10.2307/3149297

Hilligoss, B., \& Rieh, S. Y. (2008). Developing a unifying framework of credibility assessment: Construct, heuristics, and interaction in context. Information Processing \& Management, 44(4), 1467-1484. doi:10.1016/j.ipm.2007.10.001

Hinkin, T. R. (1995). A review of scale development practices in the study of organizations. Journal of Management, 21(5), 967-988. doi:10.1016/0149-2063(95)90050-0

Jansen, B. J., Sobel, K., \& Cook, G. (2011). Classifying ecommerce information sharing behavior by youths on social network sites. Journal of Information Science, 37(2), 120-136. doi:10.1177/0165551510396975

Jarvis, C. B., MacKenzie, S. B., \& Podsakoff, P. M. (2003). A critical review of construct indicators and measurement model misspecification in marketing and consumer research. Journal of Consumer Research, 3o(2), 199-218. doi:10.1086/376806

Johnson, R. E., Rosen. C. C., Chang. C-H. S., Djurdjevic, E., \& Taing, M. U. (2012). Recommendations for improving the construct clarity of higher-order multidimensional constructs. Human Resource Management Review, 22(2), 62-72. doi:10.1016/j.hrmr.2011.11.006

Katz, E., Gurevitch, M., \& Hass, H. (1973). On the use of mass media for important things. American Sociological Review, 38(2), 164-181. doi:10.2307/2094393

Kim, J. Y., Shim, J. P., \& Ahn, K. M. (2011). Social Networking service: Motivation, pleasure, and behavioral intention to use. Journal of Computer Information Systems, 51(4), 92-101. doi:10.1080/0887441 7.2011.11645505

Kline, R. B. (1998). Principles and practice of structural equation modeling. New York, USA: Guilford Press.

Korgaonkar, P. K., \& Wolin, L. D. (1999). A multivariate analysis of web usage. Journal of Advertising Research, 39(2), 53-68. 
Kuss, D. J., \& Griffiths, M. D. (2011). Online social networking and addiction: A review of the psychological literature. International Journal of Environmental Research and Public Health, 8(9), 35283552. doi:10.3390/ijerph8093528

Lancaster, G. A., Dodd, S., \& Williamson, P. R. (2004). Design and analysis of pilot studies: Recommendations for good practice. Journal of Evaluation in Clinical Practice, 10(2), 307-312. doi:10.1111/j..2002.384.doc.x

MacCallum, R. C., Browne, M. W., \& Sugawara, H. M. (1996). Power analysis and determination of sample size for covariance structure modeling. Psychological Methods, 1(2), 130-149. doi:10.1037/1082 989X.1.2.130

MacKenzie, S. B., Lutz, R. J., \& Belch, G. E. (1986). The role of attitude toward the ad as a mediator of advertising effectiveness: A test of competing explanations. Journal of Marketing Research, 23(2), 130143. doi:10.2307/3151660

McDonald, R. P., \& Ho, M. H. R. (2002). Principles and practice in reporting structural equation analyses. Psychological Methods, $7(1)$, 64-82. doi:10.1037/1082-989X.7.1.64

Mir, I. A. (2012). Consumer attitudinal insights about social media advertising: A South Asian perspective. The Romanian Economic Journal, 15(45), 265-288.

Mir, I. A. (2014). Effects of pre-purchase search motivation on user attitudes toward online social network advertising: A case of university students. Journal of Competitiveness, 6(2), 42-55. doi:10.7441/joc.2014.02.04

Mir, I. A., \& Rehman, K. U. (2013). Factors affecting consumer attitudes and intentions toward user-generated product content on YouTube. Management \& Marketing, 8(4), 637-654.

Mir, I., \& Zaheer, A. (2012). Verification of social impact theory claims in social media context. Journal of Internet Banking and Commerce, 17(1). Retrieved from http://www.arraydev.com/commerce/jibc/.

Muntinga, D. G., Moorman, M., \& Smit, E. G. (2011). Introducing COBRAs: Exploring motivations for brand-related social media use. International Journal of Advertising, 30(1), 13-46. doi:10.2501/IJA-301-013-046

Nunnaly, J. (1978). Psychometric theory. New York, USA: McGraw-Hill.

O’Donohoe, S. (1994). Advertising uses and gratifications. European Journal of Marketing, 28(8/9), 52-75. doi:10.1108/03090569410145706

Orchard, L.J., Fullwood, C., Galbraith, N., \& Morris, N. (2014) Individual differences as predictors of social networking. Journal of ComputerMediated Communication, 19(3), 388-402. doi:10.1111/jcc4.12068

Papacharissi, Z., \& Rubin, A. M. (2000). Predictors of internet use. Journal of Broadcasting \& Electronic Media, 44(2), 175-196. doi:10.1207/s15506878jobem4402_2
Park, N., Kee, K. F., \& Valenzuela, S. (2009). Being immersed in social networking environment: Facebook groups, uses and gratifications, and social outcomes. Cyberpsychology \& Behavior, 12(6), 729-733. doi:10.1089/cpb.2009.0003

Pavlou, P. A., \& Stewart, D. W. (2000). Measuring the effects and effectiveness of interactive advertising: A research agenda. Journal of Interactive Advertising, 1(1), 61-77. doi:10.1080/15252019.2000.1 0722044

Petter, S., Straub, D., \& Rai, A. (2007). Specifying formative constructs in information systems research. MIS Quarterly, 31(4), 623-656. doi:10.2307/25148814

Petrovici, D., \& Marinov, M. (2007). Determinants and antecedents of general attitudes towards advertising: A study of two EU accession countries. European Journal of Marketing, 41(3/4), 307-326. doi:10.1108/03090560710728354

Punj, G. N., \& Staelin, R. (1983). A model of consumer information search behavior for new automobiles. Journal of Consumer Research, 9(4), 366-380. doi:10.1086/208931

Rieh, S. Y., \& Hilligoss, B. (2008). College students' credibility judgments in the information-seeking process. Digital media, youth, and credibility. In M. J. Metzger \& A. J. Flanagin (Eds.), The John D. \& Catherine T. MacArthur foundation series on digital media \& learning (pp. 49-72). Cambridge, MA: The MIT Press.

Rodgers, S. (2002). The interactive advertising model tested: The role of motives in ad processing. Journal of Interactive Advertising, 2(2), 22-33. doi:10.1080/15252019.2002.10722059

Rodgers, S., Wang, Y., Rettie, R., \& Alpert, F. (2007). The web motivation inventory: Replication, extension and application to internet advertising. International Journal of Advertising, 26(4), 447-476. do i:10.1080/02650487.2007.11073028

Rosengren, K. E., Wenner, L. A., \& Palmgreen, P. (Eds.) (1985). Media gratifications research: Current perspectives. Beverly Hills, CA: Sage Publications.

Rubin, A. M. (1984). Ritualized and instrumental television viewing. JournalofCommunication, 34(3), 67-77. doi:10.1111/j.1460-2466.1984. tbo2174.x

Ruggiero, T. E. (2000). Uses and gratifications theory in the 21st century. Mass Communication \& Society, 3(1), 3-37. doi:10.1207/ S15327825MCS0301_02

Severin, W. J., \& Tankard, J. W. (1997). Communication theories: Origins, methods and uses in the mass media (4th ed.). New York, NY: Longman.

Shore, T. H., Shore, L. M., \& Thornton, G. C. III. (1992). Construct validity of self and peer evaluations of performance dimensions in an assessment center. Journal of Applied Psychology, 77(1), 42-54. doi:10.1037/0021-9010.77.1.42 
Straub, D. W. (1989). Validating instruments in MIS research. MIS Quarterly, 13(2), 147-169. doi:10.2307/248922

Tavakol, M., \& R. Dennick, (2011). Making sense of Cronbach's alpha. International Journal of Medical Education, 2, 53-55. doi:10.5116/ ijme.4dfb.8dfd

Taylor, D. G., Lewin, J. E., \& Strutton, D. (2011). Friends, fans, and followers: Do ads work on social networks? How gender and age shape receptivity. Journal of Advertising Research, 51(1), 258-275. doi:10.2501/JAR-51-1-258-275

Touré-Tillery, M., \& Fishbach, A. (2014). How to measure motivation: A guide for the experimental social psychologist. Social and Personality Psychology Compass, 8(7), 328-341. doi: 10.1111/spc3.12110

Trusov, M., Bodapati, A. V., \& Bucklin, R. E. (2010). Determining influential users in internet social networks. Journal of Marketing Research, 47(4), 643-658. doi:10.1509/jmkr.47.4.643
Weigts, W., Widdershoven, G., Kok, G., \& Tomlow, P. (1993). Patients' information seeking actions and physicians' responses in gynecological consultations. Qualitative Health Research, 3(4), 398429. doi:10.1177/104973239300300402

Wilson, T. D. (1999). Models in information behavior research. Journal of Documentation, 55(3), 249-270. doi:10.1108/EUMoo00000007145

Yamane, T. (1967). Statistics: An introductory analysis (2nd ed.). New York, NY: Harper \& Row.

Yang, B., Watkins, K. E., \& Marsick, V. J. (2004). The construct of the learning organization: Dimensions, measurement, and validation. Human Resource Development Quarterly, 15(1), 31-55. doi:10.1002/hrdq.1086

Yoo, C. Y. (2008). Unconscious processing of web advertising: Effects on implicit memory, attitude toward the brand, and consideration Set. Journal of Interactive Marketing, 22(2), 2-18.

Zaichowsky, J. L. (1985). Measuring the involvement construct. Journal of Consumer Research, 12(3), 341-352. doi:10.1086/208520 